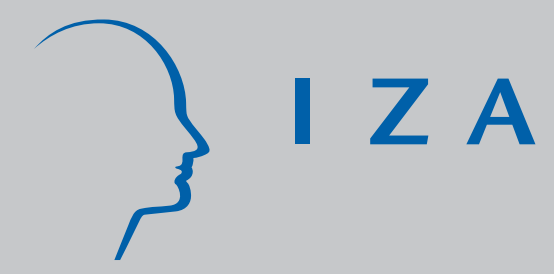

IZA DP No. 2987

Location-Specific Human Capital, Location Choice and Amenity Demand

Douglas J . Krupka

August 2007 


\title{
Location-Specific Human Capital, Location Choice and Amenity Demand
}

\author{
Douglas J. Krupka
}

IZA

\author{
Discussion Paper No. 2987 \\ August 2007
}

IZA
P.O. Box 7240
53072 Bonn
Germany

Phone: $+49-228-3894-0$

Fax: +49-228-3894-180

E-mail: iza@iza.org

\begin{abstract}
Any opinions expressed here are those of the author(s) and not those of the institute. Research disseminated by IZA may include views on policy, but the institute itself takes no institutional policy positions.
\end{abstract}

The Institute for the Study of Labor (IZA) in Bonn is a local and virtual international research center and a place of communication between science, politics and business. IZA is an independent nonprofit company supported by Deutsche Post World Net. The center is associated with the University of Bonn and offers a stimulating research environment through its research networks, research support, and visitors and doctoral programs. IZA engages in (i) original and internationally competitive research in all fields of labor economics, (ii) development of policy concepts, and (iii) dissemination of research results and concepts to the interested public.

IZA Discussion Papers often represent preliminary work and are circulated to encourage discussion. Citation of such a paper should account for its provisional character. A revised version may be available directly from the author. 
IZA Discussion Paper No. 2987

August 2007

\section{ABSTRACT \\ Location-Specific Human Capital, Location Choice and Amenity Demand}

The role of amenities in the flow of migrants has been debated for some years. This paper advances an original model of amenities that work through household production instead of directly through the utility function. Area characteristics (amenities) affect household production, causing certain kinds of human capital investments to be rewarded more than others. Area heterogeneity makes such investments location-specific, in that some areas' characteristics will reward certain kinds of knowledge more than others. This specificity along with a period of exogenous location (before migration can be carried out) - increases the opportunity costs of moving, diminishes migration flows between dissimilar locations and increases valuation of amenities which were present in the originating area. These theoretical results emphasize people's sorting across areas and thus differ from the results of the standard model of compensating differentials. Empirical tests of the model's predictions using NLSY79 data show that childhood investments affect migration flows in the way proposed by the model.

JEL Classification: R23, J61

Keywords: migration, amenities, human capital, location specificity

Corresponding author:

Douglas J. Krupka

IZA

P.O. Box 7240

D-53072 Bonn

Germany

E-mail: dkrupka@iza.org 


\section{Introduction.}

People consider many factors when deciding where to live. Obviously their potential income and expenditures in an area are two such factors. The subjective quality of life, which derives from local characteristics, is a third, all-encompassing factor. These local characteristics, or amenities, affect the quality of life because people have preferences for certain types of areas; people may be willing to pay more to live in temperate climates than in severe ones, for instance. The quality of life (QOL) literature has used the marginal migrant's willingness to pay to compute quality of life indices for various areas.

This paper models the valuation of such amenities as depending upon investments people make in their appreciation. Because people are exogenously stuck in the same location as their parents for their first 18 years, they have added incentive to invest in the appreciation of the amenities present in their origin residence. These investments are location-specific in that they are not useful in very dissimilar areas. Once these locationspecific investments are made, the opportunity costs of moving to dissimilar locations are increased, and we should thus observe migrants preferring areas that are more similar to their childhood residences. These results emphasize that population distributions are the results of people sorting into their most preferred locations, a point not stressed by the QOL literature. The paper uses geocode data from the National Longitudinal Survey or Youth, 1979 cohort, to test the prediction that exposure to certain types of areas during youth increases the likelihood of finally settling in such areas, even for long-distance migrants.

The rest of the paper is organized as follows. Section one briefly surveys the relevant literatures. Section two draws out a simple model of human capital investment 
and location-choice with exogenous assignment of original location, but with investment decisions and subsequent location determined endogenously. Section three describes the data and empirical strategy, while section four presents the results. A fifth section discusses the relevance of these results and concludes.

\section{Literature.}

People choose amenities by migrating. Sjaasted [1962] was the first to bring migration into the framework of investments in human capital, but it has always been clear that migration is driven by economic forces. Tolley [1974] and Rosen [1974] offer models which include economic forces, but allow amenities to play a part in reaching a regional equilibrium in which the "hedonic" values of amenities are "capitalized" into metropolitan wages and real estate prices. Roback [1982] and many later authors use hedonic analysis to compute all-inclusive quality-of-life (QOL) indices for metropolitan areas. ${ }^{1}$ A characteristic of these models is that in equilibrium migration is driven only by idiosyncratic factors. Wages and rents adjust to make the representative migrant indifferent between all locations.

Another branch of the amenity literature concerns the effect of amenities on migration per se. Graves [1979] and Graves et al. [1979, 1982] show evidence that amenities affect people’s migration decisions. Some authors [Florida 2000, Clark 2002] have focused on urban and cultural amenities as driving regional growth through inmigration. If amenities affect migration, it suggests that amenities have not yet been fully capitalized into wages or rents so that utility gains to migration persist. If this were the

\footnotetext{
${ }^{1}$ Greenwood [1997] and Gyourko et al. [1999] are recent reviews of the migration and quality of life literatures, respectively.
} 
case, the equilibrium assumptions underlying the QOL literature would be inappropriate. Greenwood et al. [1991] allow for such disequilibrium forces in computing state-level compensating differentials, but find that disequilibrium forces do not have large effects. This result is not surprising in light of the results in Greenwood et al. [1989], which show that amenities perform relatively poorly compared to more standard labor-market variables in predicting migration flows.

The compensating differentials which make marginal migrants indifferent between locations could come through differing wage levels or through varying returns to human capital investments. Cragg and Kahn [1997] exploit this possibility by allowing returns to human capital to vary across states. But a complete understanding of interregional wage differentials must also be based on an understanding of inter-regional differences in the distribution and type of human capital. The point of departure in this paper is to acknowledge the existence of types of human capital whose returns are location-specific. The idea of location-specificity in human capital is not new. Sjaasted [1962], Becker [1964, p. 50], and Davanzo [1982] all use or acknowledge its existence.

Many other types of specificity have been proposed. Becker, et al. [1977] propose spouse-specific human capital as a tempering factor in divorce. Neal [1995, 1999] uses industry-specificity to understand job search strategies. All of these types of capital, however, can have significant spatial implications. Industry-specific human capital, for example, will be location-specific if industries are non-uniformly distributed. Spouse-specific knowledge is location-specific as well, if the spouse does not wish to move. $^{2}$ Large amounts of firm-specific human capital would likely have a similar effect,

\footnotetext{
${ }^{2}$ Mincer [1978] and Graves and Linneman [1979] show that marital status has significant effects on the propensity of people to migrate.
} 
as shown by Bartel [1979]. Most of the concept of social capital (at least as described in Putnam [2000] and Glaeser et al. [2002]) also manifests itself as location-specific human capital.

In the model to follow, amenities do not affect the returns to human capital uniformly. The presence of amenities or disamenities puts a premium on certain kinds of human capital by making these types of human capital more productive. Because amenities vary over space, these types of human capital will have location-specific returns. The model to follow shows how this location-specificity, along with a period of forced residence (representing childhood) causes people to be more attracted to areas in which they have made significant location-specific investments. Because of the link between amenities and location-specific human capital, the theoretical result means that amenity valuation will be higher for those who have made investments in the amenity's appreciation. This goes to the heart of a second assumption of the quality of life literature: the use of a representative consumer. If people vary (as we know they do), the hedonic values computed in the QOL literature are set only by the marginal migrants and represent only their preferences. The meaning of such an index for inframarginal residents of a given area is not clear, even when the regional system is in equilibrium.

\section{Model.}

The following model includes three essential elements: exogenous original residence, the opportunity to migrate after a period of exogenous residence, and the opportunity to invest in human capital that is location specific. We assume two periods and two 
locations $[A, B]$. We assume the following conditional wage functions for each location, which are deterministic functions of two types of human capital and local population:

1) $\quad \bar{W}_{A}\left(H_{A}, H_{B} ; \pi\right), \quad \bar{W}_{B}\left(H_{A}, H_{B} ; \pi\right)$

$\pi$ represents the proportion of the population that is randomly assigned to location $A$ in the first period. Actual wage in location $l$ for individual $i$ is the conditional wage plus an idiosyncratic taste or fit component $\left(W_{l i}=\bar{W}_{l}+e_{l i}\right)$ which is assumed to be mean zero with positive variance. ${ }^{3}$ Here, wage stands in for subjective well-being. Wage and population in the second period - by which time individuals may have migrated from their exogenous origin - are represented by a prime: $\overline{W_{l}^{\prime}}=\bar{W}_{l}\left(H_{A}, H_{B} ; \pi^{\prime}\right)$. The wage functions are assumed to be concave and have no human capital cross effects:

2) $\quad \frac{\partial \bar{W}_{l}}{\partial H_{l}} \geq 0, \quad \frac{\partial^{2} \bar{W}_{l}}{\partial H_{l}^{2}} \leq 0, \quad \frac{\partial^{2} \bar{W}_{l}}{\partial H_{l} \partial H_{k}}=0 \quad \forall l \neq k$.

We define the conditional wage in $B$ in terms of the conditional wage in $A$, so that

3) $\quad \bar{W}_{B}\left(H_{A}, H_{B} ; \pi\right) \equiv \bar{W}_{A}\left(H_{B}, H_{A} ; 1-\pi\right)$.

Among other things, this means that neither type of human capital is "better" than the other and defines a distribution of labor supply $(\pi=1 / 2)$ that will make the wage functions in each location essentially identical.

Specificity implies that the two types of capital do not perform equally well in each location.

4) $\frac{\partial W_{l}}{\partial H_{l}} \geq \frac{\partial W_{k}}{\partial H_{l}}$ whenever $\pi=1 / 2$,

and

\footnotetext{
${ }^{3}$ The fit components are included to allow for regional equilibria in which each location is populated. Regional equilibria are not derived here. Interested readers are referred to Krupka [2004b] for the model's predictions about regional equilibrium.
} 
5) $\quad \frac{\partial W_{l}}{\partial H_{l}} \geq \frac{\partial W_{l}}{\partial H_{k}} \quad$ whenever $H_{l}=H_{k}$.

Note that equation 3 makes one of these definitions of specificity imply the other.

Finally, we assume for simplicity that all forms of human capital are equally costly to obtain, ${ }^{4}$ and that $p$ is the shadow price of these investments.

Given these assumptions, the first order conditions for someone starting at location $A$ implicitly define optimum investment levels for both types of human capital (indexed by subscripts $A$ and $B$ ). The intensity of investment will depend on whether the individual plans to move to location $B$ (indexed by superscript $m$ ) or stay in $A$ (indexed by superscript $S)$ :

6a) $H_{A}^{S}: \frac{\partial \bar{W}_{A}}{\partial H_{A}}+\delta \frac{\partial \bar{W}_{A}^{\prime}}{\partial H_{A}}=p$.

6b) $H_{B}^{S}: \frac{\partial \bar{W}_{A}}{\partial H_{B}}+\delta \frac{\partial \bar{W}_{A}^{\prime}}{\partial H_{B}}=p$.

6c) $H_{A}^{m}: \frac{\partial \bar{W}_{A}}{\partial H_{A}}+\delta \frac{\partial \bar{W}_{B}^{\prime}}{\partial H_{A}}=p$.

6d) $H_{B}^{m}: \frac{\partial \bar{W}_{A}}{\partial H_{B}}+\delta \frac{\partial \bar{W}_{B}^{\prime}}{\partial H_{B}}=p$.

Because the individuals know whether they will move or not when they make their investment decisions, movers will already have the optimal amount of human capital if they move. They will not want to invest more upon arrival in the new area. ${ }^{5}$

\footnotetext{
${ }^{4}$ This would appear to be a conservative assumption, since presumably it would be easier to invest in the local area $A$ than the foreign area.

${ }^{5}$ This statement assumes that potential migrants know with certainty the returns in the destination area. Later, this certainty will correspond to a potential migrant knowing the characteristics of the potential destination in every detail with complete certainty. Relaxing this unrealistic assumption would have two effects on the model. First, if investment were too little, there would be investment in the second period. Second, the uncertainty associated with the destination area will count as an additional undesirable attribute of the move choice for risk-averse migrants. Both of these effects will make migration less attractive. Such factors could be built into the model by incorporating a positive cost to migration. As discussed
} 
We can focus our analysis at the symmetric equilibrium, where $\pi=\pi^{\prime}=1 / 2$. The definition of location-specificity and the first order conditions imply that $H_{A}^{S} \geq H_{A}^{m} \geq H_{B}^{S}$ and that $H_{A}^{S} \geq H_{B}^{m} \geq H_{B}^{S}$. For simplicity, we assume $\delta=1$, so that $H_{A}^{m}=H_{B}^{m}=H^{m}{ }^{6}{ }^{6}$ Knowing the relative size of the investments will be of use later. The move/stay decision (for someone starting at $A$ ) depends upon whether an individual's net income of staying at location $A\left(N W S_{A i}\right)$ given optimal levels of investment is greater than or less than zero. In symbols, a person stays at location $A$ whenever:

$$
\begin{aligned}
N W S_{A i} & =\bar{W}_{A}\left(H_{A}^{S}, H_{B}^{S}\right)+\bar{W}_{A}^{\prime}\left(H_{A}^{S}, H_{B}^{S}\right) \\
& -\bar{W}_{A}\left(H^{m}, H^{m}\right)-\bar{W}_{B}^{\prime}\left(H^{m}, H^{m}\right) \\
& +\left(e_{a i}-e_{b i}\right)-p\left(H_{A}^{S}+H_{B}^{S}-2 H^{m}\right) \geq 0,
\end{aligned}
$$

where the first line represents the wage or income associated with staying in location $A$ both periods, the second line represents the wage or income associated with moving to location $B$ (having invested optimally for such a move), and the final line represents the difference in idiosyncratic match and capital expenses associated with the two choices. If this quantity is negative, people will move.

Omitting the prime marks (because $\pi=\pi^{\prime}=1 / 2$ implies $\bar{W}_{A} \equiv \overline{W_{A}^{\prime}}$ ), rearranging terms and using equation 3 to put the entire equation in terms of the wage in region $A$ yields:

$$
\begin{aligned}
N W S_{A i} & =2\left[\bar{W}_{A}\left(H_{A}^{S}, H_{B}^{S}\right)-\bar{W}_{A}\left(H^{m}, H^{m}\right)\right] \\
& +\left(e_{a i}-e_{b i}\right)-p\left(H_{A}^{S}+H_{B}^{S}-2 H^{m}\right) \geq 0 .
\end{aligned}
$$

However, with $\pi=\pi^{\prime}=1 / 2$ and with perfectly general human capital $H_{A}^{S}=H^{m}=H_{B}^{S}$, so the bracketed term and the price term are zero, and the move/stay condition reduces to a comparison of idiosyncratic taste or fit:

below, this does not change the qualitative results of the model. The implications for observed migration behavior are discussed in section III.

${ }^{6}$ Depending on the length of the second period and people's discount rate, $\delta$ could be greater or less than one. The theoretical result is independent of the value of $\delta$, but assuming a value of one makes the derivation more direct and cuts down on notation. 
9) $\quad N W S_{A i}\left(\pi=\pi^{\prime}=1 / 2\right.$, no specificity $)=\left(e_{a i}-e_{b i}\right) \geq 0$.

Specificity will change the levels of human capital, and the wage functions underlying the move/stay condition. If specificity increases $N W S_{A i}$, individuals will be more likely to stay in the area in which they have made local investments. ${ }^{7}$ The first order conditions with location-specificity imply that $H_{A}^{S} \geq H^{m} \geq H_{B}^{S}$. We can use a linear approximation of the $N W S_{A}$ condition to see if people will be more likely to stay in familiar areas. Location-specificity will increase the net wage of staying in location $A$ whenever

10) $2\left[\frac{\partial \bar{W}_{A}}{\partial H_{A}}\left(H_{A}^{S}-H^{m}\right)+\frac{\partial \bar{W}_{A}}{\partial H_{B}}\left(H_{B}^{S}-H^{m}\right)\right] \geq p\left(H_{A}^{S}+H_{B}^{S}-2 H^{m}\right)$.

With no specificity, this inequality is $0 \geq 0$. Finally, plugging F.O.C. 6c in for $p$, using equation 3 to switch the subscripts on the second partial in the bracketed term and some simple algebraic manipulations yield:

11) $\frac{\partial \bar{W}_{A} / \partial H_{A}}{\partial \bar{W}_{B} / \partial H_{A}} \geq \frac{H_{A}^{S}-H_{B}^{S}}{H_{A}^{S}-H_{B}^{S}}=1$,

which is always true, by definition of location-specificity. This means that, when human capital investments are location-specific, "average" individuals (those with no idiosyncratic preference for either area) will find it optimal to stay in the familiar area. Of course, a similar result is available by assuming a non-zero cost to migration. The qualitative result persists in the presence of such moving costs. The costs will cause people to be less likely to move, but location-specificity will strengthen this tendency.

\footnotetext{
${ }^{7}$ That is, individuals will need more relatively negative idiosyncratic tastes for their home area before a move becomes optimal.
} 
In general, we are not able to measure the location-specific investments described in the model. Because the empirical section to follow does not rely on the direct measurement of location-specific human capital, some discussion on how to interpret this result seems appropriate. The basic dynamic at work is that the necessity of living in the exogenously determined location in the first period makes some investment in that area's type of human capital optimal. This additional investment in local knowledge increases the opportunity cost of migrating to the other area, and thus decreases migration to areas in which local knowledge is not useful. The model shows that the derived preference for "home-like" areas is not a result of sentimentality or insensitivity to "real" economic forces. Rather, this attachment is a direct result of the incentives individuals face as children and adolescents.

Specificity could arise in the labor market because of geographical factors (location near a coast or raw material deposits), political factors (the location offering a more favorable regulatory atmosphere) or historical factors (the location historically being a center of some industry). While such factors may be endogenous in a model of regional development, to the individual they are exogenous. If these factors influence human capital investment in the real-life equivalent of the first period with exogenous location, these geographic differences will have the effect described in the model. However, since young people can migrate before they begin working, such marketoriented factors should be minor. Market-oriented human capital only affects wage in the second period, so investment in such human capital can essentially be postponed until after migration. The effect through opportunity costs will not exist. 
On the other hand, specificity in the household production sector would have the effects described in the model. Exogenously-located youth use time, energy, knowledge and their environment to produce leisure activities, such as surfing or downhill skiing. Obviously, the knowledge that makes surfing enjoyable is different than the knowledge that makes down-hill skiing enjoyable. The environmental input into these activities varies with location: waves in southern California, slopes in Colorado. Such amenities will affect the returns to certain kinds of human capital. Thus, someone randomly assigned a childhood in Los Angeles will find it optimal to learn to surf, while one randomly assigned a childhood in Denver will find it optimal to learn to ski. Having learned to enjoy the local environment more fully, these youth will be giving up more in leaving it; the opportunity cost of migration will have increased.

These location-specific investments are not specific to the home location alone, but to other locations with similar qualities. One can ski all across the Mountain Time Zone, and in the Appalachian Mountains as far south as the Carolinas. Skiing ability will also increase the attractiveness of those areas for those who have invested heavily in it. Surfing skills are perhaps more geographically limited in their usefulness.

While waves and slopes are two obvious examples of amenities that enhance the productivity of certain kinds of knowledge more than others, similar arguments hold for a number of other area characteristics. A fine symphony orchestra only increases an area's attractiveness for those with a cultivated taste in classical music. Warm winters will be less attractive to those who have learned well how to enjoy themselves in the cold. Forests are more attractive to those who have learned to enjoy hiking, camping or hunting. Knowledge like this might be observable in terms of certain expenses (classical 
CDs, winter coats, camping gear), ${ }^{8}$ but we should not expect it. One who grows up knowing that Lake Michigan is nearby in Chicago or Milwaukee may have a cultivated taste for shoreline access that one raised in Minneapolis will not. Such cultivation would include the kind modeled by Becker and Stigler [1977], but would also include a kind of creeping, almost costless kind of cultivation more aptly described as “familiarity."9

Because locations vary in their characteristics, and because area characteristics affect the returns to certain kinds of human capital, people who have become more comfortable with living in certain types of locations will be more attracted to similar places, relative to others who started in different kinds of areas. This effect will manifest itself in two ways. First, since the home location will always be more familiar than other areas, these opportunity costs will decrease migration flows generally. Straight-forward monetary moving costs would have the same effect. Second, even those moving from their origin should find similar areas more attractive, and thus be more likely to finally choose such areas than observationally similar migrants who grew up elsewhere. The empirical section that follows tests this second prediction, which is made by neither the moving cost model nor the standard model of amenities.

\section{Empirical Strategy and Data.}

In order to empirically support the model, I observe individuals’ residence histories over a substantial span of their lives. The model predicts that the area type of residence as a youth will be correlated positively with final area type. On the other hand, a more standard amenities model with amenity valuation deriving directly from a utility function

\footnotetext{
${ }^{8}$ Gray (1998) shows demand for cultural activities is increased by art lessons and classes.

${ }^{9}$ Such costless familiarity could be modeled as a type of human capital that is specific to the home location and has a shadow price of zero, at least for some minimal investment.
} 
and income constraint would predict an income effect (positive for normal amenities). Life cycle theories would also posit marital status and family size as other predictors of amenity valuation. We also might predict education to have an effect on amenity demand, since it has strong effects on most other goods and services. Thus, I run several regressions of the form:

$$
A_{T}=\gamma_{0}+\gamma_{1} \log (\text { income })+\gamma_{2} A_{0}+\gamma_{3} X+\varepsilon_{1} .
$$

Here, $A_{T}$ represents the amenities in the "terminal" location, where observations finally decide to settle down. This is the measure of amenity demand. $A_{0}$ is the same amenity measured in the origin location, which we will call amenity exposure. ${ }^{10}$ Income is the household income and $X$ is a vector of three demographic controls: education, marital status and number of children.

Because amenities are capitalized into wages and rents, it is likely that the error term will be correlated with income, biasing $\gamma_{1}$ toward zero. Therefore, I instrument for income using a battery of information including race, education, age-adjusted AFQT score, sex, marital status, occupational categories for the individual, childhood family structure variables, parental education, labor market variables for parents and spouse, childhood household reading habits, and whether individuals’ parents were foreign born. Geographical variables were not included in the instrument.

Another explanation for the predicted positive sign of $\gamma_{2}$ is that straight-forward moving costs prevent many individuals from moving. While some people who stay in their origin location are doing so for the very reasons described in the model, some are responding to financial costs alone. Because for such individuals $A_{T}=A_{0}$ by definition,

\footnotetext{
${ }^{10}$ Because real people's lives consist of more than two periods, people can have multiple origins if their parents moved frequently when they were children. Data limitations and a desire for a consistent variable lead me to use the residence at age 14 as the basis for this amenity exposure.
} 
part of the estimated effect of $\gamma_{2}$ is due only to moving costs. To rule out moving costs as an explanation, I use sample restrictions to limit our focus to movers. I present results for several different sample restrictions.

There are three dimensions on which I restrict the sample. First, there is the "time away” dimension. People who leave their home county for only one or two years may not have truly undertaken a costly move. For instance, people who leave their home county for college likely leave most of their belongings in their parents' house. Moving back to the origin is still the least financially costly location decision. To rule out this possibility, we mostly restrict our sample to those movers who stayed away from their origin location at least five years.

We can also restrict our sample based on how far an individual moves from their original location. Short distance movers are behaving according to the model, but possibly for other reasons. For instance, if people prefer to stay in the nearby area because of social connections or because job and housing search costs are lower within a metropolitan area, then these movers will have similar amenity levels in the origin and terminal location due to social connections and search costs, not the dynamics highlighted by the model. To rule out this explanation, we condition on the maximum distance the individual ever moved away from the origin. A distance of over 300-400 km would seem to be enough to get most people out of the local labor market and make social connections in the origin relatively costly to maintain.

Finally, we can condition on the distance from "home" at which the individual settles down. This most severe restriction does not allow return migration of any sort. Migrants who move away from home to explore the world, but who return later are acting 
according to the model, but the return might be because of old familial and social ties rather than familiarity with the area. Even when we restrict our sample to people who spent several years away, and thus have had ample opportunity to make new friends and family, we cannot rule out this explanation. Because we cannot observe where an individual's family and friends live, we take the origin as the probable location of most of these ties. ${ }^{11}$ Looking only at migrants who leave home and never return should rule out social ties as an explanation for any positive partial correlation between amenity exposure and demand.

To estimate equation 12, we use geocode data from the National Longitudinal Survey of Youth, 1979 cohort (NLSY79). This data file gives county of residence at birth, age 14, every year from 1979-1994, and every other year from 1994-2000. Income and demographic information for equation 12 and the first stage equation are taken from these files. Data about the counties are merged onto these files so that each respondent can be assigned an amenity exposure and final amenity demand. The NLSY79 sample is aged 36-44 in 2000. While certainly not at the end of their days, migration is much less common in this age range than at younger ages, so we take their county of residence in 2000 as a revelation of their final demand for amenities.

\footnotetext{
${ }^{11}$ Some readers have suggested using migrant stock in the terminal location as a proxy for possible social ties or information flows between destination and origin counties. Kau and Sirmans [1977] and Carrington et al. [1996] suggest that such considerations are important in understanding migration flows. Assuming that the migrant stock is a strong enough proxy to pick up such flows, the use of such a term in the present context - where we seek to understand amenity demand - is somewhat problematic. First, the sample of non-return migrants already concentrates on a relatively unrepresentative population. If (to rule out social ties as an explanation) we further exclude all those movers making common moves, the value of the remaining observations would be questionable. It is not clear what a sample of individuals making highly abnormal moves can tell us about the migration patterns or amenity demand of the population at large. Furthermore, while a large migrant stock in the destination location may decrease migration costs as in Carrington et al. [1996], such concentrations of immigrants could appear anywhere. The prediction of the model, at the population level, is that such concentrations should arise in areas similar to the area of origin. One interpretation of the results below is that they reveal such a pattern in this smaller sample of randomly selected individuals.
} 
The county information collected covers a very broad range of 67 county characteristics. Climate, topography, land-use/land-cover, area demographics and religious characteristics, and a set of area retail and cultural opportunities are all included. $^{12}$ In the interest of space, we do not dwell on any specific amenity in particular, but instead discuss the broad patterns of the results as we estimate equation 12 for all 67 area characteristics. Table A.1 in the appendix lists the variables used and gives their average demand among NLSY79 respondents left in the sample in 2000.

\section{Results.}

The full results consist of 67 separate dependant variables, and 24 different sample restrictions. Presenting all these results is not feasible here, although the detailed results are available from the author upon request. Here I present two summary measures of the 67 regressions for each sample restriction: the number of times each independent variable is significant (at the .05 level) and the average standardized effect of the exposure variable as a multiple of the standardized effect of each other dependent variable. This

Table I: Time away varies (1)

\begin{tabular}{|c|c|c|c|c|c|c|c|}
\hline & \multicolumn{2}{|c|}{ Average } & \multicolumn{5}{|c|}{ Times Significant (out of 67) } \\
\hline & obs. & adj. r-sq & Inc & Amen & Edu & Kids & Marital \\
\hline \multirow{4}{*}{$\begin{array}{l}\text { All Observations } \\
\text { one-period movers } \\
\text { two-period movers } \\
\text { three-period movers }\end{array}$} & 5887 & 0.333 & 9 & 67 & 39 & 34 & 17 \\
\hline & 4459 & 0.225 & 10 & 67 & 45 & 33 & 9 \\
\hline & 3984 & 0.181 & 9 & 67 & 46 & 35 & 7 \\
\hline & 3759 & 0.159 & 7 & 67 & 46 & 35 & 10 \\
\hline \multirow{3}{*}{$\begin{array}{l}\text { four-period movers } \\
\text { five-period movers } \\
\text { six-period movers }\end{array}$} & 3579 & 0.141 & 7 & 67 & 47 & 34 & 11 \\
\hline & 3422 & 0.127 & 6 & 66 & 46 & 32 & 12 \\
\hline & 3326 & 0.117 & 8 & 61 & 43 & 29 & 12 \\
\hline
\end{tabular}

\footnotetext{
${ }^{12}$ I would like to thank Kelly Edminston, Terry Clark, David McGranahan, Jessica Brown, Doug Noonan, Don Coursey and my Dad for help in processing the data sources used to compile this information.
} 
Table II: Time away varies (2)

\begin{tabular}{|r|c|c|c|c|c|}
\hline & & \multicolumn{4}{|c|}{ StEff(Amen) as multiple of StEff of: } \\
\cline { 2 - 6 } Sample & Avg. Obs & Inc & Edu & Kids & Marital \\
\hline All Observations & 5887 & 44.50 & 194.21 & 95.38 & 59.47 \\
\cline { 2 - 6 } one-period movers & 4459 & 18.68 & 46.30 & 47.21 & 49.90 \\
\cline { 2 - 6 } two-period movers & 3984 & 15.14 & 185.86 & 28.99 & 41.69 \\
\cline { 2 - 6 } three-period movers & 3759 & 15.48 & 20.84 & 19.39 & 31.83 \\
\cline { 2 - 6 } four-period movers & 3579 & 11.56 & 46.01 & 15.86 & 40.10 \\
\cline { 2 - 6 } five-period movers & 3422 & 10.17 & 21.82 & 20.04 & 27.40 \\
\cline { 2 - 6 } six-period movers & 3326 & 8.41 & 90.32 & 20.01 & 27.53 \\
\hline
\end{tabular}

second quantity will be referred to as the average effect ratio. ${ }^{13}$

Tables I and II show how the times significant and average effect ratios change as time away varies. The results are not terribly sensitive to changes in this condition. The average effect ratio is always at least five and the significance does not suffer as shortterm movers are purged from the sample.

Tables III and IV show that the results are also fairly robust to how far a migrant must move to be considered a mover. For migrants who stayed away at least five years, increasing the distance they must move to be counted as a migrant does lower both the

Table III: Minimum distance varies (1)

\begin{tabular}{|c|c|c|c|c|c|c|c|}
\hline \multirow[b]{2}{*}{ Sample } & \multicolumn{2}{|c|}{ Average } & \multicolumn{5}{|c|}{ Times Significant (out of 67) } \\
\hline & obs. & adj. r-sq & Inc & Amen & Edu & Kids & Marital \\
\hline $100 \mathrm{~km}$ movers & 2627 & 0.088 & 2 & 66 & 42 & 28 & 13 \\
\hline $200 \mathrm{~km}$ movers & 2251 & 0.070 & 2 & 66 & 41 & 29 & 7 \\
\hline $300 \mathrm{~km}$ movers & 2021 & 0.046 & 3 & 66 & 42 & 24 & 10 \\
\hline $400 \mathrm{~km}$ movers & 1831 & 0.042 & 5 & 66 & 39 & 20 & 13 \\
\hline $500 \mathrm{~km}$ movers & 1658 & 0.037 & 5 & 64 & 39 & 19 & 11 \\
\hline $600 \mathrm{~km}$ movers & 1552 & 0.033 & 10 & 61 & 39 & 16 & 20 \\
\hline $800 \mathrm{~km}$ movers & 1366 & 0.031 & 9 & 56 & 36 & 15 & 14 \\
\hline $1000 \mathrm{~km}$ movers & 1182 & 0.032 & 4 & 56 & 35 & 11 & 12 \\
\hline
\end{tabular}

${ }^{13}$ That is: The Average Effect Ratio (of variable k) $=67^{-1} \sum_{a=1}^{67} \gamma_{2 a} \sigma_{a} / \gamma_{k a} \sigma_{k}$. Note that since we have a strong prediction about he sign of the exposure variable, it is counted as significant only when it is significant in the expected direction. The other variables are counted significant regardless of sign. 
Table IV: Minimum distance varies (2)

\begin{tabular}{|c|c|c|c|c|c}
\hline \multirow{2}{*}{ Sample } & & \multicolumn{4}{|c}{ StEff(Amen) as multiple of: } \\
\cline { 2 - 6 } & Avg. Obs & Inc & Edu & Kids & Marital \\
\hline 100km movers & 2627 & 20.67 & 10.72 & 24.70 & 25.07 \\
\cline { 2 - 6 } $200 \mathrm{~km}$ movers & 2251 & 23.62 & 32.24 & 30.84 & 13.29 \\
\cline { 2 - 6 } 300km movers & 2021 & 32.94 & 8.90 & 9.86 & 17.78 \\
\cline { 2 - 6 } $400 \mathrm{~km}$ movers & 1831 & 13.28 & 11.20 & 8.38 & 12.27 \\
\cline { 2 - 6 } $500 \mathrm{~km}$ movers & 1658 & 7.47 & 18.72 & 7.88 & 14.95 \\
\cline { 2 - 6 } $600 \mathrm{~km}$ movers & 1552 & 5.06 & 4.94 & 7.02 & 5.19 \\
\hline $800 \mathrm{~km}$ movers & 1366 & 6.37 & 5.26 & 14.33 & 7.30 \\
\cline { 2 - 6 } $1000 \mathrm{~km}$ movers & 1182 & 6.49 & 4.02 & 48.28 & 11.90 \\
\hline
\end{tabular}

significance and the strength of exposure's effect, but in all cases it is the most often significant variable, and has the strongest standardized effect. Even for moves as distant as $1000 \mathrm{~km}$ (roughly from Chicago to Atlanta), exposure is significant $60 \%$ more often than education (the next most important variable), with standardized effects on average four times those of education.

Tables V and VI show how these results hold up when making restrictions on final distance. They show that return migration is indeed an important factor. Each table contains two panels: the top for migrants who moved at least 300km away from home,

Table V: Final distance varies (1)

\begin{tabular}{|c|c|c|c|c|c|c|c|c|}
\hline \multirow{2}{*}{$\begin{array}{l}\text { Minimum } \\
\text { Distance: }\end{array}$} & \multirow{2}{*}{$\begin{array}{c}\text { Sample } \\
\text { movers who: }\end{array}$} & \multicolumn{2}{|c|}{ Average } & \multicolumn{5}{|c|}{ Times Significant (out of 62) } \\
\hline & & obs. & adj. r-sq & Inc & Amen & Edu & Kids & Marital \\
\hline \multirow{4}{*}{$300 \mathrm{~km}$} & \multirow{4}{*}{$\begin{array}{r}\text { stayed away } \\
\text { stayed } 100 \mathrm{~km} \text { away } \\
\text { stayed } 200 \mathrm{~km} \text { away } \\
\text { stayed } 300 \mathrm{~km} \text { away }\end{array}$} & 1822 & 0.042 & 2 & 52 & 42 & 22 & 20 \\
\hline & & 1621 & 0.032 & 3 & 39 & 40 & 14 & 17 \\
\hline & & 1499 & 0.026 & 6 & 31 & 37 & 14 & 15 \\
\hline & & 1410 & 0.023 & 4 & 23 & 42 & 16 & 17 \\
\hline \multirow{6}{*}{$500 \mathrm{~km}$} & \multirow{6}{*}{$\begin{array}{r}\text { stayed away } \\
\text { stayed } 100 \mathrm{~km} \text { away } \\
\text { stayed } 200 \mathrm{~km} \text { away } \\
\text { stayed } 300 \mathrm{~km} \text { away } \\
\text { stayed } 400 \mathrm{~km} \text { away } \\
\text { stayed } 500 \mathrm{~km} \text { away }\end{array}$} & 101 & טכת ח & 5 & 16 & 10 & 11 & 21 \\
\hline & & 1337 & 0.022 & 8 & 31 & 40 & 13 & 20 \\
\hline & & 1257 & 0.020 & 9 & 16 & 40 & 13 & 19 \\
\hline & & 1203 & 0.020 & 6 & 13 & 41 & 15 & 20 \\
\hline & & 1164 & 0.021 & 9 & 12 & 38 & 16 & 19 \\
\hline & & 1124 & 0.019 & 11 & 10 & 38 & 15 & 22 \\
\hline
\end{tabular}


Table VI: Final distance varies (2)

\begin{tabular}{|c|c|c|c|c|c|c|}
\hline \multirow{2}{*}{$\begin{array}{l}\text { Minimum } \\
\text { Distance: }\end{array}$} & \multirow{2}{*}{$\begin{array}{c}\text { Sample } \\
\text { movers who: }\end{array}$} & \multirow[b]{2}{*}{ Avg. Obs } & \multicolumn{4}{|c|}{ StEff(Amen) as multiple of: } \\
\hline & & & Inc & Edu & Kids & Marital \\
\hline \multirow{4}{*}{$300 \mathrm{~km}$} & \multirow{4}{*}{$\begin{array}{r}\text { stayed away } \\
\text { stayed } 100 \mathrm{~km} \text { away } \\
\text { stayed } 200 \mathrm{~km} \text { away } \\
\text { stayed } 300 \mathrm{~km} \text { away }\end{array}$} & 1822 & 12.64 & 13.20 & 9.57 & 13.13 \\
\hline & & 1621 & 4.23 & 43.90 & 5.22 & 11.42 \\
\hline & & 1499 & 4.63 & 3.61 & 5.96 & 3.79 \\
\hline & & 1410 & 13.13 & 1.91 & 3.59 & 3.82 \\
\hline \multirow{7}{*}{$500 \mathrm{~km}$} & & & & & & \\
\hline & \multirow{6}{*}{$\begin{array}{r}\text { stayed away } \\
\text { stayed } 100 \mathrm{~km} \text { away } \\
\text { stayed } 200 \mathrm{~km} \text { away } \\
\text { stayed } 300 \mathrm{~km} \text { away } \\
\text { stayed } 400 \mathrm{~km} \text { away } \\
\text { stayed } 500 \mathrm{~km} \text { away }\end{array}$} & 1494 & 3.39 & 4.33 & 5.73 & 3.13 \\
\hline & & 1337 & 3.64 & 2.78 & 15.86 & 1.58 \\
\hline & & 1257 & 1.30 & 7.72 & 7.14 & 0.56 \\
\hline & & 1203 & 2.46 & 1.50 & 4.54 & 1.15 \\
\hline & & 1164 & 0.43 & 0.58 & 23.27 & 1.63 \\
\hline & & 1124 & 0.22 & 1.98 & 2.64 & 0.49 \\
\hline
\end{tabular}

the lower for migrants moving at least $500 \mathrm{~km}$ away. The tables show that throwing return migrants from the data (the first row of each panel) reduces significance and the average effect ratio significantly. Restricting the sample to those who never move back within $100 \mathrm{~km}$ eliminates exposure's edge in significance completely, although the average effect ratios are still comfortably grater than one. Exposure's larger effects persist even for the most severe sample restriction for $300 \mathrm{~km}$ movers. For $500 \mathrm{~km}$ movers, exposure has slightly larger effects for restrictions up to the $300 \mathrm{~km}$ final distance restriction, but not generally thereafter.

The results presented in Table V and VI are extremely conservative because they do not account for the spatial structure of the underlying distribution of county characteristics. Because counties that are close together tend to be relatively similar (compared to the population of counties), looking only at non-return migrants is forcing migrants into dissimilar counties, biasing these estimates downward. In essence, the null hypothesis that the effect of prior exposure is zero is not appropriate. To explore this possibility, I ran a series of Monte Carlo simulations in which individuals were randomly 
assigned migration histories and the models with sample restrictions were run with the new randomized data. ${ }^{14}$ In every case, the Monte Carlo sample distribution on the coefficient for exposure is centered about a negative number when the sample is restricted as in Tables V and VI. In most cases, the coefficient estimated with the real data falls outside the range of the generated sample distribution (implying a p-value below .001). For every county characteristic tested in this way, the range of sample restrictions in which exposure was significant increased. Thus, the significance of prior exposure is underestimated in Table $\mathrm{V}$ as is the size of the standardized effect of exposure (measured as the difference between the estimated coefficient and the coefficient under the true null hypothesis) in Table VI.

Given all these different sample restrictions, which are the most appropriate? To think about this question, it is useful to think of respondents as falling into one of two types. There are those individuals ("Responders") who behave according to the model by gaining familiarity through exposure to certain kinds of areas, and who become more attracted to such areas. On the other hand, some individuals ("Non-responders") simply do not become more attracted to areas in which they have grown up. Perhaps they had unhappy childhoods, or our data are not picking up multiple moves. For whatever reason, they feel no special attraction, or even a revulsion for areas like the ones in which they are observed at age 14. The problem is that, even for Non-responders, there are many reasons why they might stay in areas similar to the ones in which they lived at 14 . Moving costs and job and housing search costs all increase as one moves further from

\footnotetext{
${ }^{14}$ These results are available from the author on request. Thanks to an anonymous referee for bringing up this possibility.
} 
home. Social networks will be concentrated around old residences. The presence of these Non-responders thus biases our estimates of the effect of exposure upward.

As the sample is restricted, we throw out some Responders and some Nonresponders. At first, this helps our estimates. But as the sample restrictions become more severe, Non-responders become over-represented. A sample of only Non-responders is no more desirable than the full sample, the bias is just in the opposite direction. Somewhere between the full sample estimates and the most restricted sample estimates lie the most appropriate estimates of the relative strength of the exposure effects. Economists can obviously disagree about which restriction is most appropriate. Here, we simply observe the broad pattern of results. Prior exposure seems to have a significant and relatively large effect on amenity demand, even for fairly severe sample restrictions, although the explanatory power of the models is small. I consider this evidence to be supportive of the contention that childhood exposure leads to increased demand for amenities.

Results reported in Krupka [2004a] lend additional support to the model. First, these results show that additional experience of an area's characteristics significantly increases the strength of exposure's effect, as expected, for two-thirds of the variables examined. ${ }^{15}$ Furthermore, the significance of exposure to many of the urban amenities and socioeconomic variables is not merely an artifact of an omitted urban status variable. Inclusion of controls for the urban status of childhood residence does not undermine the strength or significance of the urban exposure variables. Similarly, for the religion and race variables, results show that controlling for respondents' own religion or race does

\footnotetext{
${ }^{15}$ Additional experience significantly decreased exposure's effect for only one amenity. Additional experience was measured as closer similarity between the characteristic of the birth and “origin” counties.
} 
not drive the exposure variable into insignificance. Finally, it shows that the significant exposure effects are not an artifact of low-education workers having a smaller labor market from which to choose. When the respondent's education is interacted with the exposure variable, the interaction is significant less than $20 \%$ of the time, and is more often positive (suggesting more educated workers value familiarity more) than negative. All in all, these further results add additional support to the model's validity.

\section{Conclusion.}

This paper has presented a model in which people are able to invest in an appreciation of their home area's attributes. The availability of such investment opportunities increases the attractiveness of similar areas in subsequent periods. The qualitative result, that amenity exposure increases the demand for such amenities, is novel in that it is not part of the standard model of amenity valuation or inter-area migration and location choice.

Empirically, the results are broadly supportive of the model's hypothesis. In a random sample of 1970s youth, it is found that individuals tended to settle in areas similar to those in which they grew up, even when the sample is restricted to longdistance migrants. Some of this pattern is attributable to return migration, but the pattern persists in a weakened form when return migrants are excluded from the sample.

These results are important for several reasons. First, they offer a better understanding of the origins of amenity valuation. In the canonical model of amenities, differences in demand only arise due to unexplained taste differences. Here, amenity valuations differ in a predictable manner, based on observable circumstances. The assumption that people do not vary in their tastes for amenities is an assumption of 
convenience underlying the quality of life literature, either explicitly or through the use of a representative consumer framework. While this assumption is obviously not descriptively true, the results depend importantly on the existence of “enough" marginal migrants to fill up any city and keep the real-wage demand to live in an area perfectly elastic. While this paper cannot speak to the accuracy of this less heroic assumption, it suggests that it is an assumption worth examining further.

The interpretation of the hedonic model implicit in the quality of life literature is contrasted starkly with the interpretation given in the labor economics literature. In labor economics, the hedonic model presented by Rosen [1974] is generally taken as a model of sorting. Workers with strong preferences for certain job characteristics sort into positions with firms who have a low cost of providing such characteristics to their workers. DeLeire and Levy [2004] show evidence consistent with such sorting in the context of the risk of on-the-job fatality. Kreuger and Schkade [2007] have even more direct evidence concerning people's sociability and the intensity of on-the-job interpersonal interaction. Because of this fundamental difference in the interpretation of the hedonic model, an all-encompassing “quality of work” index has never been a goal in the labor economics literature. For whatever reason, such an index has been a central feature in our understanding of the interaction between metropolitan prices and local amenities.

The results also have implications outside the narrow field of amenity valuation. Knowing that a person is more, or less, likely to appreciate a certain area's charms is of use to job search committees, for instance, as they strategize over job offers every spring. 
Avowed ice-fishers from Wisconsin will probably not be as serious about a job in Miami, whatever their protestations at the interview.

The model also has implications for metropolitan growth. Cheshire and Magrini [2006] find evidence that climate was an important determinant of local population growth in Europe between 1980 and 2000, but only within national boundaries. Such a pattern could be explained by people's unwillingness to migrate across old national boundaries because of an acquired adaptation to local languages, cultures and institutions.

Furthermore, Klepper [2003] has shown that an important determinant of geographic concentrations of some industries is the tendency of firm spin-offs to stay in the same area as the parent firm. Moving costs and social ties are part of this tendency for new spin-offs not to fall far from the tree, but an acquired taste for the area would reinforce this effect. Berry and Glaeser [2005] offer a model of agglomeration based on this dynamic. New firms form near parent firms, and hire similar mixes of workers. This leads areas with high proportions of educated workers to become even more educated, and causes income divergence. Thus, the added cost of moving to an unfamiliar area may be an important factor in regional as well as metropolitan agglomeration.

From a broader perspective, Glaeser and Gyourko [2005] advance a model where the slow depreciation of housing keeps populations in declining cities from plummeting, while depressing real estate values. Similarly, Glaeser and Kohlhase [2003], describe the world as a place where agglomeration forces freed from high transport costs throw up larger and more sprawling cities. Only durable infrastructure and people’s idiosyncratic tastes for certain areas prevent the long run equilibrium of a few mega-cities from being attained. This paper reframes those idiosyncratic tastes as depreciable forms of capital 
similar to built infrastructure or the pre-existing housing stock. These tastes could be thought of as inertia preventing the achievement of the static equilibrium. From the perspective of tied residents and governments of the declining areas, however, these tastes (along with the infrastructure and housing stock) would be seen as offering the area a chance to regroup or reinvent itself before utter collapse occurs.

In conclusion, the model predicts an attraction to certain area types over and above an attraction to a specific area. This new perspective on amenity valuation offers some important insights into how amenities affect location decisions. It also has implications for several related streams of research.

\section{References.}

Bartel, Ann P., “The Migration Decision: What Role does Job Mobility Play?” American Economic Review, LXIX (1979), 775-786.

Becker, Gary S., Human Capital: A theoretical and Empirical Analysis with Special Reference to Education (Chicago, IL: University of Chicago Press, 1993).

Becker, Gary S., Elisabeth Landes, and Robert T. Michael, “The Economics of Marital Instability,” The Journal of Political Economy, LXXV (1977), 1141-1187.

Becker, Gary S. and George Stigler, "De Gustibus Non Est Disputandum,” American Economic Review, LXVII (1977), 76-90.

Berry, Christopher R. and Edward L. Glaeser, “The Divergence of Human Capital Levels across Cities," Harvard Institute of Economic Research Discussion Paper Number 2091, 2005: http://post.economics.harvard.edu/hier/2005papers/2005list.html

Carrington, William J., Enrica Detragiache, Tara Vishwanath, "Migration with Endogenous Moving Costs,” American Economic Review, LXXXVI (1996), 909930.

Cheshire, Paul C. and Stefano Magrini, "Population Growth in European Cities: Weather matters - but only nationally,” Regional Studies, XL (2006), 23-37. 
Clark, Terry Nichols, "Urban Amenities: Lakes, Opera, and Juice Bars, do they drive development?” in Terry Nichols Clark, ed. The City as an Entertainment Machine: Researches in Urban Policy, Vol. 9, (New Amsterdam: Elsevier, 2003), 103-140.

Cragg, Michael, Matthew Kahn, "New Estimates of Climate Demand: Evidence from Location Choice,” Journal of Urban Economics, XLII (1997), 261-284.

DaVanzo, Julie, "Repeat Migration in the United States: Who Moves Back and Who Moves On?” The Review of Economics and Statistics, LXV (1983), 552-559.

DeLeire, Thomas and Helen Levy, "Worker Sorting and the Risk of Death on the Job," Journal of Labor Economics, XXII (2004), 925-953.

Florida, R., "Bohemia and economic Geography," Journal of Economic Geography, II (2002a), 55-71.

Glaeser, Edward L. and Joseph Gyourko, “Urban Decline and Durable Housing," Journal of Political Economy, CXIII (2005), 345-375.

Glaeser, Edward L. and Janet Kohlhase, "Cities, regions and the decline of transport costs,” Journal of Economics, LXXXIII (2003)197-228.

Glaeser, Edward L. David Laibson and Bruce Sacerdote, "An Economic Approach to Social Capital,” The Economic Journal CVII (2002), F437-F458.

Graves, P.E., "A Life-Cycle Empirical Analysis of Migration and Climate, by Race," Journal of Urban Economics VI (1979), 135-147.

Graves, P. E. and P. D. Linneman, "Household Migration: Theoretical and Empirical Results,” Journal of Urban Economics, VI (1979), 383-404.

Graves, P.E., and J. Regulska, "Amenities and Migration over the Life-Cycle, by Race," in D.B. Diamond and G.S. Tolley, ed., The Economics of Urban Amenities. (New York: Academic Press, 1982), 211-222.

Gray, Charles M. "Hope for the Future? Early Exposure to the Arts and Adult Visits to Art Museums," Journal of Cultural Economics XXII (1998), 87-98.

Greenwood, Michael J., "Internal Migration in Developed Countries," in ed. The Handbook of Population and Family Economics, Vol. 1B, (Amsterdam: NorthHolland, 1997), 1- 48.

Greenwood, Michael J., Gary L. Hunt, "Jobs versus Amenities in the Analysis of Metropolitan Migration,” Journal of Urban Economics, XXV (1989), 1-16. 
Greenwood, Michael J., Gary L. Hunt, Dan S. Rickman, and George I. Treyz, "Migration, Regional Equilibrium, and the Estimation of Compensating Differentials," The American Economic Review, LXXXI (1991), 1382-1390.

Gyourko, J., M. Kahn, and J. Tracy, "Quality of Life and Environmental Comparisons," in E.S. Mills and P. Cheshire, ed., The Handbook of Regional and Urban Economics, Vol. 3, (Amsterdam: North-Holland, 1999), 1413-1454.

Kau, James B. and C. F. Sirmans "The Influence of Information Cost and Uncertainty on Migration: a Comparison of Migrant Types," Journal of Regional Science XVII (1977), 89-96.

Klepper, Steven "The Geography of Organizational Knowledge" mimeo. Carnegie Mellon University, 2003.

Krueger, Alan B. and David Schkade, " Sorting in the Labor Market: Do Gregarious Workers Flock to Interactive Jobs?” NBER Working Paper No. 13032, April 2007. http://www.nber.org/papers/w13032

Krupka, Douglas J. Location-specific Human Capital, Migration and Amenities. Unpublished PhD. Thesis, University of Chicago, 2004a.

_ "Location-Specific Human Capital, Migration and Amenities," Georgia State University URAG Working Paper No. 04-06 2004b: http://aysps.gsu.edu/urag/workingpapers/2004/urag_0406.pdf

Mincer, Jacob, "Family Migration Decisions,” Journal of Political Economy, LXXXVI (1978), 749-773.

Neal, Derek, "Industry-specific Human Capital: Evidence from Displaced Workers," Journal of Labor Economics, XIII (1995), 653-677.

_ “The Complexity of Job Mobility among Young Men," Journal of Labor Economics, XVII (1999), 237-261.

Putnam, Robert, Bowling Alone: The Collapse and Revival of American Community, (New York: Simon and Schuster, 2000).

Roback, Jennifer. "Wages, rents, and the Quality of Life." The Journal of Political Economy, XC (1982), 1257-78.

Rosen, Sherwin, "Hedonic Prices and Implicit Markets: Product Differentiation in Pure Competition,” The Journal of Political Economy, LXXXII (1974), 34-55.

Sjaasted, Larry A., "The Costs and Returns of Human Migration.” Journal of Political Economy, LXX (1962), 80-93. 
Tolley, G.S., “The Welfare Economics of City Bigness,” Journal of Urban Economics, I (1974), 324-345. 
Appendix A: TableA.1: Amenity variables used in analysis.

\begin{tabular}{|c|c|c|c|c|}
\hline Type & Variable & Mean & StDev & Panel? \\
\hline \multirow{8}{*}{ 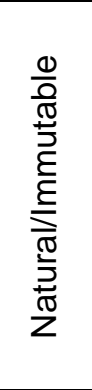 } & Avg. January Temp. & 37.677 & 12.694 & N/A \\
\hline & Avg. January Hours Sun & 156.324 & 39.790 & N/A \\
\hline & Avg. July Temp. & 76.223 & 5.424 & N/A \\
\hline & Avg. July Humidity & 59.771 & 14.196 & N/A \\
\hline & Topography Code & 8.579 & 7.087 & N/A \\
\hline & Percent Water & 10.390 & 15.652 & N/A \\
\hline & In(Percent Water) & 5.726 & 1.743 & N/A \\
\hline & Combined Score (of above) & 1.215 & 3.117 & N/A \\
\hline \multirow{10}{*}{ 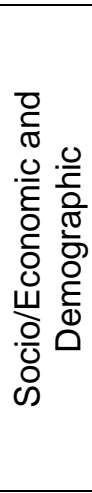 } & Urban Dummy & 0.767 & 0.423 & Yes \\
\hline & Urban Influence (decreasing) & 2.279 & 2.031 & No \\
\hline & Rural/Urban Continuum (decreasing) & 1.917 & 2.328 & No \\
\hline & Population Density & 1807.313 & 5225.238 & Yes \\
\hline & Crime Rate per 100,000 & 5941.497 & 2932.850 & Yes \\
\hline & Local Unemployment & 4.501 & 2.510 & Yes \\
\hline & Percent College educated & 19.686 & 7.733 & Yes \\
\hline & percent Black & 0.154 & 0.150 & Yes \\
\hline & percent White & 0.669 & 0.216 & Yes \\
\hline & Racial Diversity index & 0.567 & 0.212 & Yes \\
\hline \multirow{20}{*}{ 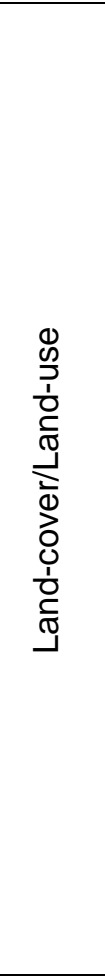 } & Percent Deciduous Forest & 0.159 & 0.213 & No \\
\hline & Percent Evergreen Forest & 0.078 & 0.142 & No \\
\hline & Percent Mixed Forest & 0.038 & 0.081 & No \\
\hline & Percent Shrubland & 0.076 & 0.200 & No \\
\hline & Percent Grassland, Herbaceous & 0.046 & 0.115 & No \\
\hline & Percent Woody Wetlands & 0.030 & 0.066 & No \\
\hline & Percent Emergent Herbaceous Wetlands & 0.016 & 0.061 & No \\
\hline & Percent Perennial Ice and Snow & 0.000 & 0.002 & No \\
\hline & Percent Orchards, Vineyards Other & 0.009 & 0.035 & No \\
\hline & Percent Pasture, Hay & 0.105 & 0.142 & No \\
\hline & Percent Row Crops & 0.135 & 0.221 & No \\
\hline & Percent Small Grains & 0.011 & 0.051 & No \\
\hline & Percent Fallow & 0.001 & 0.009 & No \\
\hline & Percent Urban, Recreational Grass & 0.009 & 0.021 & No \\
\hline & Percent Low-intensity Residential & 0.097 & 0.121 & No \\
\hline & Percent High-intensity Residential & 0.040 & 0.096 & No \\
\hline & Percent Commerc'l Industr'l Transport'n & 0.033 & 0.056 & No \\
\hline & Percent Bare Rock, Sand, Clay & 0.004 & 0.018 & No \\
\hline & Percent Quarries, Strip Mines, Gravel Pits & 0.002 & 0.004 & No \\
\hline & Percent Transitional & 0.003 & 0.008 & No \\
\hline
\end{tabular}


Appendix A: Table A.1 (cont.): Amenity variables used in analysis.

\begin{tabular}{|c|c|c|c|c|}
\hline Type & Variable & Mean & StDev & Panel? \\
\hline \multirow{7}{*}{ 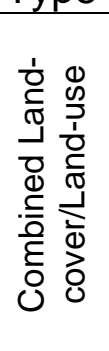 } & Percent Urban Uses & 0.179 & 0.212 & No \\
\hline & Percent Agricultural & 0.260 & 0.266 & No \\
\hline & Percent Wetland & 0.046 & 0.096 & No \\
\hline & Percent Ugly Stuff & 0.009 & 0.020 & No \\
\hline & Percent Natural State & 0.443 & 0.284 & No \\
\hline & Percent Open & 0.383 & 0.304 & No \\
\hline & Percent Forest & 0.275 & 0.272 & No \\
\hline \multirow{12}{*}{ 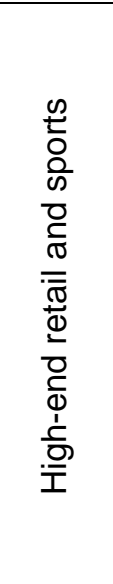 } & No. Starbucks Stores & 6.25 & 16.48 & No \\
\hline & Starbucks per Million & 3.47 & 7.24 & No \\
\hline & No. Brewpubs & 3.63 & 5.27 & No \\
\hline & Brewpubs per Million & 5.46 & 9.76 & No \\
\hline & No. Juicebars & 5.41 & 19.34 & No \\
\hline & Juicebars per Million & 2.32 & 3.87 & No \\
\hline & No. Whole Foods Stores & 0.61 & 1.97 & No \\
\hline & Whole Foods per Million & 0.27 & 1.33 & No \\
\hline & Sum of above Per Cap Z-scores & .00 & 2.35 & No \\
\hline & No. Professional Sports Teams & 1.80 & 2.60 & Yes \\
\hline & No. Bike Events & 4.35 & 7.67 & No \\
\hline & Teams plus Bike Events & 6.15 & 9.24 & No \\
\hline \multirow{5}{*}{ 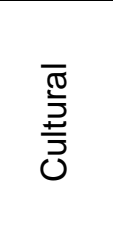 } & Number of Rare Book Stores & 1.564 & 3.546 & No \\
\hline & Number of Research Libraries & 1.061 & 1.782 & No \\
\hline & Number of Opera Companies & 0.973 & 2.187 & No \\
\hline & Number of Museums & 1.448 & 2.060 & No \\
\hline & Sum of Cultural Amenities & 5.046 & 7.996 & No \\
\hline \multirow{5}{*}{ 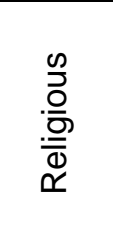 } & Religious Diversity Index & .348 & .140 & Yes \\
\hline & Religions present & 45.954 & 22.010 & Yes \\
\hline & $\%$ unaffiliated & .498 & .130 & Yes \\
\hline & $\%$ Catholic & 215 & .153 & Yes \\
\hline & \% Jewish & .020 & .033 & Yes \\
\hline
\end{tabular}

Note: means and standard deviations are for the sample of NLSY79 respondents in the year 2000, not the population of US counties. 